\title{
War Criminality: \\ A Blank Spot in the Collective Memory of the Ukrainian Diaspora
}

J O H N - PA U L H I M KA

This paper tackles the touchy question of atrocities committed by Ukrainians during the Second World War as a component, or rather its absence as a component, of the identity consciousness of the Ukrainian diaspora. ${ }^{1}$ The paper goes very much against the grain of that diaspora's current consensus. In fact, I am trying to write here a text that is indigestible for that consensus, that is aimed at dissenting from it and creating a space for dissent. I have not conducted an exhaustive study of the relevant texts of the diaspora, but that is hardly necessary for a paper such as this. Instead, I have concentrated on current electronic media and recent years of The Ukrainian Weekly, supplemented with a retrospective sampling of articles from Svoboda ${ }^{2}$ and the volume on Ukrainian-Jewish relations that came out of an important conference held in $1983 .{ }^{3}$

Anyone who consults the media, especially the electronic media, of the Ukrainian diaspora in North America cannot but be struck by how much attention it devotes to the issue of suspected war criminals. ${ }^{4}$ This has been going on for some time. The press, and Ukrainian-diaspora scholarship as well, 5 followed with concern the workings of the Deschênes Commission, which was struck in 1985 to investigate war criminals in Canada. The press also closely followed the American and Israeli legal proceedings against Ukrainian-American John Demjanjuk, who was suspected of being the sadistic camp guard known as "Ivan the Terrible." Diaspora press accounts depicted the trial as a travesty of justice. It has also portrayed 
the search for war criminals more generally as a witch-hunt, ${ }^{6}$ harming almost exclusively innocent people and tarnishing the reputation of Ukrainians as a whole. There has been almost no attempt on the part of the Ukrainian diaspora to confront the issue of war criminality in a less defensive and more soul-searching manner. (The few exceptions will be mentioned below.)

Instead, there persists a deafening silence about, as well as reluctance to confront, even well-documented war crimes, such as the mass murder of Poles in Volhynia by the Ukrainian Insurgent Army (UPA) 7 and the cooperation of the Ukrainian auxiliary police in the execution of the Jews. ${ }^{8}$ In his submission to the Deschênes Commission in 1986 John Sopinka, counsel for the Ukrainian Canadian Congress, stated that Ukrainian nationalist organizations "were not in any way allied with the Nazis." 9 It has also been denied that the Ukrainian movement in World War II had any ideological predisposition which could have facilitated participation in genocidal actions. UPA veteran and military historian Lev Shankovsky, for example, asserted at a round-table discussion that organized anti-Semitism "never existed in Ukraine. But there exists a myth about Ukrainian anti-Semitism" promoted by Moscow. ${ }^{10}$

In the diaspora one frequently encounters a double standard in discussing war crimes and crimes against humanity perpetrated by Ukrainians as opposed to those perpetrated against Ukrainians. Memoirs and eyewitness accounts, for example, are considered untrustworthy evidence for the former, but trustworthy for the latter; that is, Jewish or Polish first-hand accounts of Ukrainian war crimes are dismissed as biased, while an important Ukrainian victimization narrative, the famine of 1932-33, has relied primarily on just such eyewitness accounts. ${ }^{11}$ The argument is made that no order has ever been discovered instructing the UPA to kill Polish civilians in Volhynia. ${ }^{12}$ On the other hand, that the famine of 1932-33 was the result of deliberate policy is never questioned, even though this too remains without its "smoking gun" (as of course does the Jewish Holocaust). The crimes of Polish police in Nazi service are taken to provide some measure of explanation or justification for the attack on Polish villages in Volhynia, ${ }^{13}$ but never do Ukrainian diaspora authors suggest that Ukrainians should be held collectively responsible for the crimes of the Ukrainian police in German service. 
Linked to the denial of war criminality, although also motivated by other factors, is the construction of Ukrainian victimization narratives. ${ }^{14}$ The most important of these concerns the famine in Soviet Ukraine in 1932-33, which Ukrainians in the diaspora frequently contrast and connect with the Holocaust. ${ }^{15}$ Yaroslav Bilinksy set out his position at the UkrainianJewish conference held in 1983 , which happened to be the $50^{\text {th }}$ anniversary of the famine. Professor Bilinsky denied "a causal connection between alleged collaboration of Jewish-born Communists in the collectivization of agriculture and the Great Famine and any proven collaboration of Ukrainian-born extremists in the Holocaust." Yet he maintained that "each community is bound to ask pointed questions about the share of guilt and that each national community may draw premature conclusions and erect stereotypes. To obviate the emergence and cultivation of dangerous stereotypes on the Ukrainian side, let us study the responsibility for the Great Famine as carefully as many Jews are studying the responsibility for the Holocaust. Both logically and morally, the two tragedies are equivalent. Genocide is genocide." 16 Later at the conference, in the round-table discussion, he made more explicit his view that Ukrainian participation in the Holocaust was to be understood in roughly the same terms as Jewish participation in the famine. ${ }^{17}$

Victor Borisow, addressing a Famine-Genocide commemorative meeting in Bloomington in 2003 complained: "Many of us are pained by the realization that everyone on the planet knows about the Holocaust, but few have even heard about the Holodomor." He identified two reasons for this: 1) "Hitler lost the war, Russia won the war." 2) "Russia... has spent tons of money and decades of effort to slander and discredit anything and everything Ukrainian. Ukrainians, even those who still wear Nazi concentration camp tattoos on their arms, are routinely branded as Nazi sympathizers or collaborators, simply to discredit their message." Borisow also linked the Ukrainian famine and Holocaust causally: "Although Hitler and Stalin hated each other, they also studied each other's methods. When it was clear that Russia had gotten away with such massive genocide in Ukraine, Hitler felt free to proceed with the Holocaust."18

In an internet debate in the spring of 2002 the historian Mark Tauger denied that the Ukrainian famine was artificially contrived. Ukrainiandiaspora scholars countered that this reflected "widespread double standards," "a strong refusal among academics and journalists to place Soviet and Nazi crimes against humanity on the same level." The 
comparison was made to Holocaust denial. ${ }^{19}$ More recently a contributor to E-Poshta stated that for denying that the Ukrainian famine was genocide, Tauger as well as Lynne Viola and Moshe Lewin should be "relegated to hell's dung heap of history reserved for the most morally bankrupt liars and propagandists." To him, their views were of one cloth with those who claimed that "no one really died in the gas chambers at Auschwitz." 20 Tauger's substantive argument, that the famine was in part generated by a change in the way Soviet authorities estimated harvest size, ${ }^{21}$ has not been confronted by diaspora scholars or publicists.

Frequently diaspora authors urge fellow Ukrainians to follow the example of the Jews and produce a more detailed, more convincing narrative of their own holocaust. The claim is often made that the Ukrainians suffered as much as the Jews, indicating a competion in the intensity of victimization. From numerous examples, let me cite a few. At the same round-table discussion in 1960 where he denied the existence of Ukrainian anti-Semitism, Lev Shankovsky said: "The Jews should be an example for us of how to illuminate our recent tragic history." 22 In 1980, in a letter to Svoboda, Joseph Iwaniv asked: "Can we produce the names of the guilty and dates and places as readily as the Jews can when asked about the Holocaust?" 23 Another author in Svoboda later that year declared: "The Ukrainian 'Holocaust' was no less terrible than the Holocaust of the Jews." 24 At the Ukrainian-Jewish conference of 1983 Yaroslav Bilinsky spoke on this same topic: "We must finally write a basic history of Ukrainian martyrology, which would at the very least match in quality Hilberg's work on the destruction of the Jews!" 25 When in January 2000 Ukrainian Prime Minister Viktor Yuschenko suggested that Ukraine might build a Holocaust museum, ${ }^{26}$ Lubomyr Luciuk wrote that Ukrainians instead needed "a national museum hallowing the memory of the many millions of Ukrainians murdered during the $20^{\text {th }}$ century... Ukrainians today need to be reminded of the great price their ancestors paid for independence, just as all Jews and official visitors remember when they visit Israel's Yad Vashem."27

Other victimization narratives prominent in the diaspora include the internment of Ukrainians in Canada during World War $\mathrm{I}^{28}$ and the expulsion of Ukrainians from their home territories in southeastern Poland in 1947 (Akcja Wista). ${ }^{29}$

The Ukrainian Canadian Civil Liberties Association has opposed state support for the erection in Canada of a museum devoted exclusively to the Holocaust. The UCCLA's Director of Research, Lubomyr Luciuk, formulated the objections thus: 
No further federal, provincial, or municipal funding... should be provided for this project unless assurances are made, publicly, that the proposed Canadian Museum for Human Rights will be inclusive in its concept and contents. Will this museum, for example, host a permanent exhibit dealing with Canada's first national internment operations and their traumatic consequences for Ukrainians and other Europeans unjustly imprisoned as 'enemy aliens' in 1914-1920? And will the proposed Holocaust Gallery hallow the memory of all victims of Nazi tyranny? What about the many millions more who suffered Communist oppression, whether they perished in the genocidal Great Famine of 1932-1933 in Soviet Ukraine... or in Pol Pot's 'killing fields'? Regardless of the undeniable generosity of those boosting this project, we must have confirmation, before the first shovel of earth is turned, that any such museum will not deliberately or otherwise elevate the suffering of any one community over others. ${ }^{30}$

Before leaving this aspect of our topic, let me just explicitly clarify my position in the hopes that I can avoid at least some misunderstandings about it. I am not saying that the famine or the other components of the victimization narratives do not deserve historical research and reflection, nor that evil should be ignored, nor that the memory of the dead should not be held sacred. But I object to instrumentalizing this memory with the aim of generating political and moral capital, particularly when it is linked to an exclusion from historical research and reflection of events in which Ukrainians figured as perpetrators not victims, and when "our own" evil is kept invisible and the memory of the others' dead is not held sacred. There is an analogy that, for all its faults, might be useful for me to invoke. I write here in much the same way as would a North American Jew who feels all the horror of the Holocaust, but who is disturbed to see this tragedy exploited to further the agenda of various identity and political projects (e.g., the defence of Israel), particularly when it is linked to an exculpating narrative (e.g., vis-à-vis the Palestinians). 31

The positions adopted by the Ukrainian diaspora have to be understood in context. The most articulate segment of the diaspora are the Western Ukrainians who left Ukraine after World War II, which is the target group for insinuations and accusations of war crimes, and particularly their descendents. The older cohort had witnessed the results of NKVD mass murders in the summer of 1939 and they were keenly aware of the 
exhumation in Vinnytsia in 1943 of mass graves of murdered Soviet prisoners. They knew also of the brutal methods employed by the Soviets in their repression of UPA right after the war. Some of them had experience with murderous Nazi rule in the Reichskommissariat Ukraine, and almost all knew someone whom the Germans had sent to a concentration camp for belonging to the Ukrainian underground. From their point of view, what was done to the Ukrainians was the primary narrative of the war.

Furthermore, the Ukrainian diaspora has objected to what it considers to be uneven treatment of Nazi and Soviet crimes against humanity. They feel it is unfair that only Nazi and Nazi-associated criminals have been prosecuted for what they did in Ukraine and that no member of the former Soviet apparatus has been tried for murder. An example of what the diaspora finds galling is an article that appeared in the British Guardian and then was circulated by E-Poshta. The article described a certain Basya Chaika who, in the words of the Guardian correspondent, "was a zealous communist sitting on a military tribunal which dispensed execution orders for "traitors of the motherland" " in Konotop, Ukraine in the 1940s. In Basya Chaika's own words: "I was very radical and uncompromising... I had to sign death warrants more than once..." The Basya Chaika story was presented in the context of an internet project to recreate "life in the shtetls, the eastern European Jewish villages razed in the Holocaust." As the E-Poshta commentator remarked, the journalist "seems to be oblivious of the fact that the subject of his article was an executioner of innocent people in Ukraine." 32 The Ukrainian Canadian Civil Liberties Association has called for an inquiry into Soviet war criminals in Canada and for the deportation of "those who lied about their criminal activities upon entering Canada." 33

Finally, the Ukrainian diaspora has been put on the defensive by what it perceives to be slurs on Ukrainians as a whole in newspapers and television. Sensational articles about alleged "Nazi war criminals" appearing in the mainstream media are denounced, sometimes in intemperate terms (particularly in diaspora-Ukrainian electronic media). ${ }^{34}$ The diaspora reacted negatively to the 1980 made-for-TV movie "Holocaust" because it "depicted Ukrainians as Nazi collaborators rather than victims of the Third Reich." 35 Perhaps the most notorious case of misrepresentation of Ukrainians was the segment "The Ugly Face of Freedom" aired in 1994 on the CBS network program "60 Minutes."36 
Although the denial of incidents of war criminality and a one-sided focus on Ukrainian victimization are prevalent in the Ukrainian community in North America, no community is monolithic, and there have been and are some exceptions to the rule.

One was the late Ivan L. Rudnytsky, a scholar possessed of great civil courage. He questioned the view commonly accepted in diaspora historiography that the Bandera movement underwent a democratic transformation in the second half of 1943 and in 1944 . He specifically criticized the xeonophobia of OUN, in particular its attitude toward the Jews during World War II and its "conscious campaign of 'cleansing the land' of Polish population." 37 At the 1983 Ukrainian-Jewish conference, in response to Yaroslav Bilinsky's call for Jewish scholars to examine Jewish participation in Stalinist crimes, Ivan Rudnytsky said: "Everybody should make some house cleaning first within his own group and it would be improper for Ukrainians to tell Jewish scholars what they have to do with Jewish history. This is their problem, but we should begin now to clean our own house, and we have not been good enough at it." 38

Marco Carynnyk raised the question of wartime Ukrainian antiSemitism in what was then the most intellectually respectable journal of the diaspora, Suchasnist'. ${ }^{39} \mathrm{He}$ has continued to work on this issue, both as a scholar ${ }^{40}$ and a creative writer (the unfinished "Furious Angels"). This stream in his oeuvre has made him unpopular in some circles.

Sister Sophia Senyk has criticized the Greek Catholic church in Ukraine for its uncritical attitude towards UPA. In an article published in the journal of the Keston Institute, Religion, State $\mathcal{E}$ Society, she wrote: "While some of its members were no doubt idealistic freedom fighters, the UIA $[=\mathrm{UPA}]$ also has on its records numerous massacres of civilian population and burnings, just as Nazi and communist military formations do." Excerpts from Sister Sophia Senyk's article were circulated by EPoshta under the title "Vicious Attack on the Ukrainian Catholic Church." The words previously cited were highlighted in bold. ${ }^{41}$

I myself have also frankly discussed Ukrainian collaboration in the murder of Jews during World War II. 42

Occasionally, expressions of frustration with the dominant discourse appear in letters to The Ukrainian Weekly. Nicholas Sawicki expressed his reservations about a column by Myron Kuropas entitled "Holocaust Exploitation"; the title, he said, was "hardly appropriate for a newspaper of this standing." 43 George A. Nestor objected to some of the 
newer terms being used for the famine, including "Famine-Genocide" and "Famine-Holocaust." "Both words [Holocaust and Genocide] aptly apply to the catastrophe that befell European Jews during World War II. We should not be piggybacking off the Jews: it diminishes us both." 44

The opening of Soviet archives makes it intellectually more difficult for the diaspora to remain in denial concerning war crimes perpetrated by Ukrainian militia and police in German service and Ukrainian nationalist units. A major study of the destruction of the Jews in Eastern Galicia documents the participation of Ukrainian police in the execution of Jews. ${ }^{45}$ There has also appeared a monograph specifically devoted to the Belarusian and Ukrainian police which provides a more detailed account of their criminal activities. 46 UPA's atrocities against civilians have been documented in riveting archivally based studies by Jeffrey Burds, ${ }^{47}$ and he is currently working on a book-length, revisionist study of UPA. Volodymyr Serhiichuk published a volume of documents on the Organization of Ukrainian Nationalists (OUN) and UPA that was meant to cast the nationalists in a favorable light. Nonetheless he included a document from an UPA unit in Volhynia that reported on its annihilation of Polish villages in the spring of $1943 .{ }^{48}$ As more archival research is conducted, it is probable that more such information will come to light. Of course, the results of scholarly research are in most cases slow to be integrated into collective memory, but this is especially so when they are not easily accommodated into the existing narrative.

It has also become more difficult to maintain the innocence of Ukrainian national ideology in light of recent research. It is now clear that Ukrainian nationalism in Galicia was already highly racialized in the late $19^{\text {th }}$ century ${ }^{49}$ and had developed an elaborate anti-Jewish discourse. ${ }^{50}$ Anti-Semitic articles appeared regularly in the interwar Western Ukrainian press. ${ }^{51}$ During the war OUN leader Yaroslav Stetsko expressed his support for German-style eliminationist anti-Semitism. ${ }^{52}$ As I have described elsewhere, in the spring of 1943 the best of the Ukrainian papers under German occupation, Krakivs'ki visti, was tasked with printing a series of original anti-Semitic articles. The paper was able to enlist some prominent figures, including several who were influential in North-American diaspora publications after the war: Anatol Kurdydyk, who edited Vil'ne slovo in Toronto and Novyi shliakh and Postup in Winnipeg; Luka Lutsiv, who for many years was an editor of Svoboda; Oleksandr Mokh, who ran the publishing house Dobra knyzhka out of 
Toronto. ${ }^{33}$ Also, since the 1920s Western Ukrainian nationalism had promoted ruthlessness towards national enemies: enemies were to be destroyed not forgiven, and the strong were to crush the weak. ${ }^{54}$ Interwar and wartime Ukrainian nationalism was quite different from Nazism, but it did grow out of some of the same impulses and it led to somemurderous actions.

A painful yet honest assessment of Ukrainian participation in wartime atrocities is long overdue for the diaspora. A number of postwar societies have come to terms with the dark side of their wartime past, most notably the Germans and also, more recently, the French. The publication of Jan T. Gross's Neighbors has touched off some self-examination in Poland about Polish attitudes and actions with regard to the Jews during and right after the war. Discussing Gross's book, Janine P. Holc has written: "If a nonJewish Pole claims Chopin as part of her collective inheritance, she must also acknowledge significant acts of violence or brutality. For Gross, selecting only commendable deeds as part of one's national identity is a facile act of self-indulgence and not a genuine engagement with one's actual collective identity." 55 I would not go quite so far, but only because I distrust the conception of an "actual collective identity." What I would say is that we need the construction of a more complex, more reflective, more difficult collective memory. Perhaps this is not for all, but there has to be a space created for those who want to maintain a relation to the Ukrainian identity but also want to move beyond a rhetoric of denial and victimization, a rhetoric sounding increasingly shrill and hollow. We need a healthier collective memory firmly rooted in truthfulness.

Moreover, the Ukrainian diaspora has to reach out to and communicate with the other. Only soul-searching can open the door to reconciliation and to the elaboration of an understanding of the past that can be shared by Ukrainians, Jews and Poles. Otherwise the situation will remain as it is today, with several competing hermetic narratives of what happened during the war. The Ukrainian diaspora narrative, which had never been very convincing to outsiders, is becoming even less so. It is time to revise what we remember. 


\section{ENDNOTES}

1 I owe a debt of thanks to those who read and discussed a draft of this paper with me, not all of whom share my views: Chrystia Chomiak, David Marples, Alan Rutkowski, Sister Sophia Senyk, and Andriy Zayarnyuk.

2 I am grateful to Taras Kurylo who surveyed Svoboda for 1950, 1960, 1970, 1980.

3 Ukrainian-Jewish Relations in Historical Perspective, ed. Peter J. Potichnyj and Howard Aster (Edmonton: Canadian Institute of Ukrainian Studies, 1988).

4 For example, on the website of the Ukrainian Canadian Congress (http://www.ucc.ca) one can find "Canada's War Crimes Program 1998-2001: Lesson Learned" and "Ukrainians during World War II." Numerous press releases on war crimes can be found at the site of the Ukrainian Canadian Civil Liberties Association (http://www.uccla.ca/pressreleases/warcrimes). E-Poshta regularly circulates material on war crimes, such as "War Crimes Report - Canada" 10 July 2001, "Canadian War-Crimes Process is a Farce and Insulting" 12 April 2002, "The Dispensing of Canadian Justice - Letter to Cabinet" 8 June 2002.

5 Yury Boshyk, ed., Ukraine during World War II: History and Its Aftermath: A Symposium (Edmonton: Canadian Institute of Ukrainian Studies, 1986). See especially Part II: History and Its Aftermath: Investigating War Criminals in Canada and the United States.

6 For example: Lubomyr Luciuk, “Wasyl Odynsky a Victim of ModernDay Witch-Hunt," Ukrainian Weekly, 25 March 2001. Matthew T. Connolly, "Luciuk Commentary Much Appreciated," Ukrainian Weekly, 13 May 2001. Other terminology can also be found: "...lobby-inspired show trials." Eugene Harasymiw, "Letter to Edmonton Journal Regarding War Crimes Issue," Ukrainian Weekly, 8 October 2000.

7 "We need a media watchdog that will monitor the press and distribute information and demand corrections. Just last week, a writer on the New York Daily News editorial board wrote an article which stated that during World War II, Ukrainians massacred Polish Catholics." Roman Iwasiwka, "Yes, We Should Hire a PR Firm," 
Ukrainian Weekly, 30 January 2000. Typical is a reference to "the commemoration of the so-called 1943 events in Volyn, during which the Ukrainian Insurgent Army (UPA) is accused of destroying Polish settlements and murdering from 30,000 to 60,000 Poles." Emphasis added. Oksana Zakydalsky, "Commemorations of 1943 Events in Volyn: Perspective of Ukrainians in Poland," Ukrainian Weekly, 8 June 2003. "In 2003 Polish authorities are planning to make [sic] the anniversary of what they refer to as the 'Slaughter in Volyn' - the alleged killings of a large number of ethnic Poles by the Ukrainian underground in the Volyn region of Ukraine in 1943." Emphasis added. "Treasure Trove of Ukrainain Historical Archives Discovered in Poland," E-Poshta, 19 February 2003.

$8 \quad$ For an eminent Ukrainian political scientist in the 1980s it was still a question whether Ukrainians "served only as guards or also shot the Jews." Yaroslav Bilinsky, "Methodological Problems and Philosophical Issues in the Study of Jewish-Ukrainian Relations during the Second World War," in Ukrainian-Jewish Relations, ed. Potichnyj and Aster, p. 380. On the denial of the culpability of the Ukrainian police, see: John-Paul Himka, “Ukrainian Collaboration in the Extermination of the Jews During the Second World War: Sorting Out the Long-Term and Conjunctural Factors," in The Fate of the European Jews, 1939-1945: Continuity or Contingency, ed. Jonathan Frankel (New York, Oxford: Oxford University Press, 1997), Studies in Contemporary Jewry 13 (1997): 186 n. 11; also: “Ukrainians during World War II," Ukrainian Canadian Congress position paper, 19 June 1999.

10 "Pro problemu antysemityzmu v Ukraini," Svoboda, 3 February 1960.

11 Classic texts are: S.O. Pidhainy, et al., eds., The Black Deeds of the Kremlin: A White Book, vol. 1: Book of Testimonies (Toronto: Ukrainian Association of Victims of Russian Communist Terror, 1953) and James E. Mace and Leonid Heretz, eds., Oral History Project of the Commission on the Ukraine Famine, 3 vols. (Washington: U.S. G.P.O., 1990).

12 Taras Kuzio, "Commemorating 1943 Events in Volyn," Kyiv Post, 10 April 2003. Taras Kuzio, "How Poland is Commemorating the Volyn Events of 1943 the Wrong Way," Ukrainian Weekly, 25 May 2003.

13 This is rather cryptically put in Kuzio, "Commemorating 1943 Events in Volyn." Kuzio writes that "an important factor in the Volhynian conflict" was "when Ukrainian policemen who fled to 
the UPA were replaced by the Nazis with local Poles." There is a similar statement in Zakydalsky, "Commemorations of 1943 events." The actions of Poles in the Schutzmannschaften are the usual justification provided by Ukrainian nationalists for the attacks of UPA on the Polish civilian population.

14 John Gregorovich, chairman of the Ukrainian Canadian Civil Liberties Association: "More often than not Ukrainians have been portrayed as villains rather than as the victims that they truly were." "Holocaust Education Is Supported by Ukrainian Canadian Community," Ukrainian Weekly, 31 October 1999. Historian Andreas Kappeler has noted that because of their 20th-century experience, Ukrainians have developed a martyrology that plays a large role in their national mythology. "But at the same time they sometimes forget that Ukrainians could be found not only among the victims, but also among the perpetrators of the totalitarian regimes." Andreas Kappeler, Der schwierige Weg zur Nation: Beiträge zur neueren Geschichte der Ukraine (Vienna: Böhlau, 2003), p. 19.

15 The issue of the famine was frequently raised by Ukrainian Americans in connection with the John Demjanjuk trial. Glenn Sharfman, "The Quest for Justice: The Reaction of the UkrainianAmerican Community to the John Demjanjuk Trials," Journal of Genocide Research 2, no. 1 (2000): 68, 70, 78. “At a time when political leaders are... demanding reparation for Jewish Holocaust victims, those who died in the Ukrainian genocide are being ignored." Maria Lewytzkyj, "Great Famine Commemoration Bears Witness to Genocide," Ukrainian Weekly, 14 November 1999 (quoting Volodymyr Kurylo). “...the holocaust-famine.” George V. Mylton, "Books Expose Famine-Genocide," Ukrainian Weekly, 8 October 2000. "...the Ukrainian holocaust inflicted upon the Ukrainian people by the Soviet government during the artificially created Great Famine of 1932-1933." Ihor Sawon, "Famine Memorial United Our Community," Ukrainian Weekly, 3 December 2000. Comparing Ukrainian history textbooks written in Ukraine to the one by Toronto historian Orest Subtelny, a Swedish scholar wrote: "In none of the surveyed Ukrainian history textbooks is the conscious comparison between the Famine and the Holocaust prominent, as it was in the North American case. On the contrary, it is altogether absent, save in Orest Subtelny's presentation of what the Famine represents for the Ukrainian community." Johan Öhman, "From 
Famine to Forgotten Holocaust: The 1932-1933 Famine in Ukrianian Historical Cultures," in Klas-Göran Karlsson and Ulf Zander, eds., Echoes of the Holocaust: Historical Cultures in Contemporary Europe (Lund: Nordic Academic Press, 2003), p. 242.

17 "Round-Table Discussion," in Ukrainian-Jewish Relations, ed. Potichnyj and Aster, p. 486.

18 "Victor Borisow's Keynote Address at Commemoration," Ukrainian Weekly, 19 October 2003.

19 Taras Kuzio, "Denial of Famine-Terror Continues Unabated," RFE/RL Poland, Belarus, and Ukraine Report, 4, no. 23 (12 June 2002).

20 Peter Borisow, "So-called Omissions in the Ukrainian Famine Bibliography," E-Poshta, 22 May 2003. Borisow lumped these scholars together with pro-Soviet propagandists Douglas Tottle and Jeff Coplon. See the judicious comments of David Marples, "In Defence of the Ukrainian Famine Bibliography," E-Poshta, 22 May 2003.

21 Mark B. Tauger, "The 1932 Harvest and the Soviet Famine of 19321933," Slavic Review 50, no. 1 (Spring 1991).

22 "Pro problemu antysemityzmu v Ukraini."

23 Joseph Iwaniv, "Documentation of Our Holocaust Needed," Svoboda, 30 March 1980.

24 L. Stakhniv-Diachenko, "Novyny z Ligy proty zneslavlennia ukrains'koho imeni," Svoboda, 10 June 1980.

25 Bilinsky, "Methodological Problems," p. 387. See also "Round-Table Discussion," p. 483.

26 "Prime Minister Viktor Yuschenko's Address to Holocaust Conference," Ukrainian Weekly, 19 March 2000.

27 Lubomyr Luciuk, "Museum Must Recall All Who Were Killed," Ukrainian Weekly, 16 April 2000. Another letter on the same issue opined: "One of the last things the world needs is yet another Holocaust museum. It is also the very last thing Ukraine needs." Eugene Harasymiw, “Is Ukraine's PM Merely Being PC?” Ukrainian weekly, 16 April 2000.

28 The Ukrainian Canadian Civil Liberties Association was founded "in 1984 to meet the defamatory accusations that 'Ukrainian war criminals' were being harboured in Canada." Later: "Mandated by the Ukrainian Canadian community to negotiate a timely and honourable Ukrainian Canadian Redress Settlement Agreement for 
the unjust internment of Ukrainian Canadians as 'enemy aliens,' UCCLA has organized symposia, submitted numerous articles to the Canadian and Ukrainian press and distributed educational materials widely..." http://www.uccla.ca/about/ (accessed 21 May 2003).

29 "Declaration of the Ukrainian World Congress on the Occasion of the 55th Anniversary of 'Akcja Wisla' in Poland," 12 April 2002, archived in E-Poshta, 22 May 2002.

30 "Museum Must Include All Victims," letter to the editor, Winnipeg Free Press, 15 April 2003.

31 It is appropriate at this juncture to quote Ukrainian Weekly's columnist Myron Kuropas: “Certain Jewish American leaders are determined to keep the Holocaust alive in order to promote 'guilt'... Sensing a great opportunity to elevate American consciousness of Jewish victimhood, other Jewish organizations, academics and individuals signed on. The Holocaust has since become big business. It keeps Jewish organizations financially solvent, produces countless books, articles and films, and it protects Israel from ever being perceived in an unattractive light." There is no trace here of a reflection that his criticism of the practices he identifies among the Jews may also have some relevance to the Ukrainian diaspora. He does, though, link the Holocaust with the famine: “...The powerful Jewish lobby... has convinced many that the Holocaust was a uniquely Jewish event... To suggest that the destruction of 7 million Ukrainians by the Bolsheviks in the 1932-1933 famine in Soviet Ukraine was perhaps just as evil as the Holocaust is to dishonor in some grotesque way the murder of 6 million Jews by the Nazis." Myron B. Kuropas, "The Demjanjuk Debacle Revisited," Ukrainian Weekly, 3 March 2002. He had expressed similar ideas earlier: Myron B. Kuropas, "Manipulating the Holocaust," Ukrainian Weekly, 5 September 1999. Myron B. Kuropas, "Holocaust Exploitation," Ukrainian Weekly, 20 August 2000.

32 "Guardian Article about a Jewish Communist 'Hanging Judge' in Ukraine," E-Poshta, 7 January 2003.

33 "Ukrainian Canadians Call for Inquiry on Soviet and Communist War Criminals in Canada," UCCLA media release, 9 July 2002.

34 In a letter dated 27 September 2002 and circulated on infoukes and EPoshta, Will Zuzak referred to "the pimps in the news media, who have sold their souls to the Holocaust Industry." 
"Strike While It's Hot," Svoboda, 27 April 1980.

36 The Ukrainian Canadian Congress issued a detailed analysis of this segment: “'The Ugly Face of Freedom': A Position Paper." See also: Terry Harasym, "60 Minutes: An Anti-Ukrainian Scandal," Ukrainian Canadian Herald, December 1994, p. 8.

37 Ivan Lysiak-Rudnyts'kyi, “Natsionalizm i totalitaryzm (Vidpovid' M. Prokopovi)," Journal of Ukrainian Studies 7, no. 2 (13) (Fall 1982): 83-85.

38 “Round-Table Discussion," p. 491.

39 Marko Tsarynnyk, "Til'ky i iest' u nas voroh - nashe sertse," Suchasnist', October 1984.

40 Karel C. Berkhof and Marco Carynnyk, "The Organization of Ukrainian Nationalists and Its Attitude toward Germans and Jews: Iaroslav Stets'ko's 1941 Zhyttiepys," Harvard Ukrainian Studies 23, no. 3-4 (1999):149-84.

41 Sister Sophia's article originally appeared in Religion, State $\mathcal{E}$ Society 30, no. 4 (2002). The excerpts were circulated in E-Poshta of 21 March 2003. E-Poshta was alerted to the article by Taras Kuzio. The e-mail address of the editor of Religion, State $\mathcal{E}$ Society was provided so that readers could express their views directly to him. Himka, "Ukrainian Collaboration."

43 Nicholas Sawicki, "Ethnic Tensions and Wise Decisions," Ukrainian Weekly, 3 September 2000. Kuropas's article has been cited above.

44 George A. Nestor, "Famine Terminology Is Problematic," Ukrainian Weekly, 18 May 2003.

45 Dieter Pohl, Nationalsozialistische Judenverfolgung in Ostgalizien 1941-1944: Organisation und Durchführung eines staatlichen Massenverbrechens (Munich: R. Oldenbourg Verlag, 1997), pp. 148, 217-19, 260, 366.

46 Martin Dean, Collaboration during the Holocaust: Crimes of the Local Police in Belorussia and Ukraine, 1941-44 (New York: St. Martin's Press, published in association with the United States Holocaust Memorial Museum, 2000). But see my reservations about this book in a review forthcoming in Polin.

47 Jeffrey Burds, “AGENTURA: Soviet Informants' Networks and the Ukrainian Rebel Underground in Galicia, 1944-1948," East European Politics and Societies 11, no. 1 (Winter 1997): 89-130. Jeffrey Burds, "Gender and Policing in Soviet West Ukraine, 1944- 
1948," Cahiers du Monde russe 42 / 2, no. 3-4 (April-December 2001): 279-319.

48 "In the village of Kuty, Shumsk raion, a whole Polish colony was burned down (86 households), and the population was destroyed for collaboration with the gestapo and German authorities... In Verba raion the Polish colony Nova Novytsia was burned down (40 households) for collaboration with the German authorities. The population was destroyed... For active collaboration with the Germans in this same village [Bihal, Derazhne raion] the Polish colony was destroyed." Volodymyr Serhiichuk, OUN-UPA v roky viiny. Novi dokumenty i materialy (Kyiv: Dnipro, 1996), pp. 311-12. See also I.I. Il'iushyn, OUN-UPA i ukrains'ke pytannia $v$ roky druhoi svitovoi viiny (v svitli pol's'kykh dokumentiv) (Kyiv: Natsional'na Akademiia Nauk Ukrainy, Instytut istorii Ukrainy, 2000).

49 Andriy Zayarnyuk, "Framing the Ukrainian Peasantry in Habsburg Galicia, 1846-1914 (With a Focus on the Sambir Area" (PhD thesis: University of Alberta, 2003), chapter 8.

50 John-Paul Himka, "Ukrainian-Jewish Antagonism in the Galician Countryside during the Late Nineteenth Century," in UkrainianJewish Relations, ed. Potichnyj and Aster, pp. 111-58.

51 Shimon Redlich, "Jewish-Ukrainian Relations in Inter-War Poland as Reflected in Some Ukrainian Publications," Polin 11 (1998): 23246.

52 Berkhof and Carynnyk, "The Organization of Ukrainian Nationalists and Its Attitude toward Germans and Jews."

53 John-Paul Himka, "Krakivski visti and the Jews, 1943: A Contribution to the History of Ukrainian-Jewish Relations during the Second World War," Journal of Ukrainian Studies 21, no. 1-2 (Summer-Winter 1996): 81-95. I refrained from naming Anatol Kurdydyk in that article because he was then still alive. (See p. 88.) An obituary of Kurdydyk appeared in Ukrainian Weekly on 15 July 2001 and a warm appreciation by R.L. Chomiak on 2 September 2001.

54 Janusz Radziejowski, "Kształtowanie się oblicza ideowego radykalnego nacjonalizmu ukraińskiego (1917-1929)," in Ewa Grześkowiak-Turczyk, Polska - Polacy - mniejszości narodowe (Wrocław: 1992), pp. 317-18.

55 Janine P. Holc, "Working through Jan Gross's Neighbors," Slavic Review 61, no. 3 (Fall 2002): 465. 